\title{
PERUBAHAN SIKAP AKSEPTOR SEBELUM DAN SESUDAH KONSELING TENTANG PEMERIKSAAN ULANG PASCA PEMASANGAN IUD
}

\author{
Eny Pemilu Kusparlina \\ Akademi Kebidanan Muhammadiyah Madiun \\ Email : pemilu77@yahoo.co.id
}

\begin{abstract}
The results BKKBN Center (2018) found that the acceptor inspection afterinstallation of the IUD and some of them do not exercise control on the groundsthere was no suggestion from the officer, did not know and no complaints. Thereason is because the officer did not provide full counseling about the IUD andside effects that may arise after the installation, or due to lack of staff knowledgeabout these devices that cause they do not provide complete and correctinformation. One way to handle it is by counseling. Counseling is an attempt to help resolve conflicts, obstacles and difficulties in meeting our needs, as well as efforts to improve mental health. The purpose of this study was to identify changes in attitude acceptors before and aftercounseling on post-installation re-examination of the IUD. The design of this study was a one group pre test - post test, the population of IUD acceptors in the working area Banjarejo Health Center Madiun City some 54 people with a sample ofsome 47 people. The number of samples that do not meet the criteria of thesample as many as 7 people, so the number of samples that meet the criteria of the sample as many as 40 people. Data were collected with questionnairs measuringinstruments covered by using Likert scale before and after counseling. Results of research prior to counseling 18 acceptors (45\%) had a positive attitudeand 22 acceptors (55\%) having a negative attitude. After counseling obtained 25acceptors (62,5\%) ang 15 acceptors (37,5\%) having a negative attitude. Statistical test Wilcoxon Match Pairs Test = 5,513. Because the count $Z>Z$ table(5,513>1,96), so that $H o$ refused. This means that there is a change in attitudeacceptors before and after counseling on post-installation re -examination of theIUD. Therefore, counseling should be done continuously to increase thepercentage of acceptors who perform post-installation re-visit the IUD.
\end{abstract}

Keywords: Counseling IUD, IUD Acceptor Attitude

\section{PENDAHULUAN}

Konseling merupakan salah satu upaya untuk membantu mengatasi konflik, hambatan dan kesulitan dalam memenuhi kebutuhan kita, sekaligus sebagai upaya peningkatan kesehatan mental. Konseling merupakan satudiantara bentuk upaya bantuan yang secara khusus dirancang untuk mengatasi persoalanpersoalan yang kita hadapi (Latipun, 2016).

Konseling pra dan pasca tindakan pemasangan IUD dapat dilakukan oleh dokter /bidan. Konseling ini meliputi penjelasan spesifik tentang prosedur yang akan dilaksanakan (pra, selama dan pasca) serta penjelasan lisan / instruksi tertulis asuhan mandiri (BKKBN.2018).

Hasil penelitian Badan Koordinasi Keluarga Berencana Nasional (BKKBN) Pusat (2018) tentang faktor- faktor yang mempengaruhi pemakaian (IUD), menemukan bahwa akseptor melakukan pemeriksaan (kontrol) Intra Uteri setelah pemasangan Dvice IUD dan sebagian diantaranya tidak melakukan kontrol dengan alasantidak ada anjuran dari petugas, tidak tahu dan tidak ada keluhan. Ditinjau dari alasan akseptor tidak melakukan kontrol kemungkinan karena 


\section{JURNAL DELIMA HARAPAN 2021}

petugas tidak memberikan konseling secara lengkap tentang IUD dan efek samping yang mungkin timbul setelah pemasangannya, atau karena kurangnya pengetahuan petugas tentang alat tersebut yang menyebabkan mereka tidak memberikan informasi secara lengkap dan benar. Hal-hal yang menjadi hambatan akseptor tidak melakukan control ulang diantaranya yaitu usia, tingkat pendidikan, bekerja, merasa tidak ada keluhan, sosial ekonomi, jarak tempat pelayanan, tidak ada dukungan dari keluarga (suami), perilaku petugas kesehatan, adanya perasaan malu. Hal ini termasuk dari sikap individu dan keluarga.

$$
\text { Saat ini gerakan Keluarga }
$$

Berencana (KB) sedang berusaha
meningkatkan mutu para pelaksana, pengelola dan peserta Keluarga Berencana (KB) untuk meningkatkan penggunaan Keluarga Berencana $(\mathrm{KB})$ oleh masyarakat. Untuk itu kita sebagai petugas kesehatan terutama bidan yang berfungsi sebagai penyuluh dan salah satu penggerak program Keluarga Berencana (KB) di wilayah harus terlebih dahulu menguasai materi untuk mendukung program Keluarga Berencana (KB). Dengan bekal pengetahuan yang mendalam ditambah dengan pengalaman yang selama ini telah diperoleh di lapangan, diharapkan petugas kesehatan (bidan) dapat memberikan informasi dan motivasi yang jelas dan benar kepada masyarakat terutama pasangan usia subur (PUS) secara dini (Hartanto, 2014).

Salah satu alat kontrasepsi yang efektif dan berjangka panjangdibandingkan dengan alat kontrasepsi yang lain adalah IUD. Walaupun angka peserta Keluarga Berencana (KB) aktif di Indonesia telah cukup tinggi 52,54\%; sekitar $24 \%$ berhenti menggunakan kontrasepsi sebelum mencapai satu tahun, terutama karena mengalami efek samping kontrasepsi atau masalah kesehatan lainnya. Beberapa penelitian menunjukkan bahwa peserta Keluarga Berencana (KB) yang mendapat konseling Keluarga Berencana (KB), angka putus pakainya lebih rendah daripada peserta yang tidak mendapat konseling Keluarga Berencana

(KB) (BKKBN, 2018).

Di Madiun pada semester I hingga bulan September tahun 2018 jumlah akseptor IUD mencapai 63,40\% atau sekitar 1685 orang (www.kompas.com.akseptor IUD di Madiun, 2018). Jumlah akseptor IUD di wilayah kerja Puskesmas Banjarejo sebanyak 852 orang.Di Desa Banjarejo Kecamatan Taman akseptor aktif IUD sebanyak 154 orang. Yang melakukan kunjungan ulang sebanyak 100 orang, sedangkan 54 orang tidak pernah melakukan kunjungan ulang. Angka kegagalan untuk alat kontrasepsi IUD yaitu 1- 3 kehamilan per 100 wanita per tahun (Hartanto, 2014). Angka kegagalan IUD di wilayah Desa Banjarejo Kecamatan Taman sebanyak 2 orang. Kegagalan IUD tersebut disebabkan oleh banyak faktor, salah satunya karena akseptor tidak melakukan pemeriksaan ulang pasca pemasangan IUD.

\section{METODE PENELITIAN}

Jenis penelitian ini adalah praexperimental. Desain yang akan digunakan dalam penelitian ini adalah one grouppre test - post test. Pendekatan yang digunakan peneliti adalah pendekatan"one shot models". Populasi dalam penelitian ini adalah akseptor IUD di wilayah kerja Puskesmas Banjarejo Desa Banjarejo sejumlah 54 orang. Tehnik sampling yang digunakan adalah Simple Random Sampling. Setelah dihitung ditemukan jumlah sampel 47 orang, jumlah sampel yang tidak memenuhi kriteria sampel sebanyak 7orang, Jadi jumlah sampel yang memenuhi kriteria sampel sebanyak 47 orang. Alat ukur yang digunakan dalam penelitian ini adalah kuesioner tertutup dengan menggunakan skala Likert.

Dalam penelitian ini menggunakan studi komparatif dengan membandingkan sikap akseptor sebelum dan sesudah konseling tentang pemeriksaan ulang pasca pemasangan IUD. Uji statistiknya menggunakan uji Wilcoxon Match PairsTest dengan taraf kesalahan 0,025 . 


\section{JURNAL DELIMA HARAPAN 2021}

\section{HASIL PENELITIAN}

Tabel 1. Distribusi Frekuensi Responden Berdasarkan Usia Akseptor

\begin{tabular}{cccc}
\hline No & Usia & Frekuensi & Persentase \\
\hline 1. & $<20$ & 0 & 0 \\
2. & $20-35$ & 27 & $67,5 \%$ \\
3. & $>35$ & 13 & $32,5 \%$ \\
\hline & Jumlah & 40 & $100 \%$ \\
\hline
\end{tabular}

Berdasarkan tabel 1 dapat diketahui bahwa yang berusia $<20$ tahun sebanyak 0 akseptor $(0 \%)$, yang berusia 20-35 tahun sebanyak 27 akseptor $(67,5 \%)$, yang berusia $>35$ tahun sebanyak 13 akseptor $(32,5 \%)$.

Tabel 2. Distribusi Frekuensi Responden Berdasarkan Tingkat Pendidikan

\begin{tabular}{cccc}
\hline No & Usia & Frekuensi & Persentase \\
\hline 1. & SD & 18 & $45 \%$ \\
2. & SMP & 11 & $27,5 \%$ \\
3. & SMA & 11 & $27,5 \%$ \\
4. & Perguruan & 0 & $0 \%$ \\
& Tinggi & & \\
\hline & Jumlah & 40 & $100 \%$ \\
\hline
\end{tabular}

Berdasarkan tabel 2 dapat diketahui bahwa akseptor dengan pendidikan terakhir SD sebanyak 18 akseptor (45\%), SMP sebanyak11 akseptor $(27,5 \%)$, SMA sebanyak 11 akseptor (27,5\%), PerguruanTinggi sebanyak 0 akseptor $(0 \%)$.

Tabel 3. Analisis perubahan sikap akseptor sebelum dan sesudah Konseling Tentang Pemeriksaan Ulang Pasca Pemasangan IUD

\begin{tabular}{cccccc}
\hline \multirow{2}{*}{ No } & \multirow{2}{*}{ Sikap } & \multicolumn{2}{c}{$\begin{array}{c}\text { Sebelum } \\
\text { Konseling }\end{array}$} & \multicolumn{2}{c}{$\begin{array}{c}\text { Sesudah } \\
\text { Konseling }\end{array}$} \\
\cline { 3 - 6 } & & Frekuensi & $\%$ & Frekuensi & $\%$ \\
\hline 1. & Positif & 18 & 45 & 25 & 62,5 \\
2. & Negatif & 22 & 55 & 15 & 37,5 \\
\hline & Jumlah & 40 & 100 & 40 & 100 \\
\hline
\end{tabular}

Berdasarkan tabel 3 dapat diketahui bahwa ada perubahan angka pada skala sikap akseptor sebelum dan sesudah konseling tentang pemeriksaan ulang pasca pemasangan IUD yaitu sebelum konseling, akseptor yang bersikap positif sebanyak 18 responden (45\%) kemudian meningkat sesudah konseling menjadi 25 responden $(62,5 \%)$. Sementara yang bersikap negatif sebelum konseling sebanyak 22 responden $(55 \%)$ kemudian turun menjadi 15 responden $(37,5 \%)$.

Berdasarkan perhitungan data manual dengan uji Wilcoxon Match Pairs Test dengan taraf kesalahan 0,025 didapatkan $\mathrm{z}$ hitung sebesar 5,513, sedangkan harga kritis pada $\mathrm{z}$ tabel sebesar 1,96. Kesimpulannya yaitu keputusan bahwa Ho ditolak. Perhitungan menggunakan komputer dengan bantuan analisis statistik aplikasi SPSS didapatkan hasil 5,516. Taraf kesalahan 0,025, sehingga $5,516>0,025$, kesimpulan yang diambil adalah Ho ditolak. Sehingga, menyatakan bahwa ada perubahan sikap akseptor sebelum dan sesudah konseling pascapemasangan IUD.

\section{PEMBAHASAN}

1. Sikap Akseptor Sebelum Konseling Tentang Pemeriksaan Ulang Pasca Pemasangan IUD

Berdasarkan hasil penelitian tentang perubahan sikap akseptor IUD di Desa Banjarejo Kecamatan Taman Kota Madiun dengan jumlah sampel 40 orang, didapatkan bahwa 45\% akseptor IUD memiliki sikap positif tentang pemeriksaan ulang pasca pemasangan IUD dan 55\% akseptor IUD memiliki sikap negatif tentang pemeriksaan ulang pasca pemasangan IUD.

Menurut Notoatmodjo, 2015, sikap selalu terbentuk atau dipelajari dalam hubungannya dengan objek -objek tertentu, yaitu melalui proses persepsi terhadap objek tersebut. Hubungan yang positif ataupun yang negatif antara individu dengan objek tertentu, akan menimbulkan sikap tertentu pula dari individu terhadap objek tersebut. Dalam hal ini sikap akseptor tentang konseling pemeriksaan ulang pasca pemasangan IUD termasuk kategori negatif karena kurang adanya perasaan yang mendukung atau memihak terhadap konseling ini.

Menurut Notoatmodjo, 2015, bila 


\section{JURNAL DELIMA HARAPAN 2021}

seseorang mempunyai sikap yang negatif pada seseorang, orang tersebut akan mempunyai kecenderungan untuk menunjukkan sikap yang negatif pula. Sikap seseorang terhadap obyek sikap akan dipengaruhi oleh usia dan tingkat pendidikan akseptor, demikian pula dengan sikap akseptor IUD terhadap konseling pasca pemasangan.

Usia dapat mempengaruhi pengetahuan seseorang, semakin cukup usia, maka tingkat pengetahuan seseorang akan lebih matang dalam berpikir dan menerima informasi (Sumekto, 2018). Usia dapat mempengaruhi kemampuan seseorang dalam menyerap informasi dan menggunakan persepsi. Semakin dewasa usia seseorang dimungkinkan lebih sulit dilakukan modifikasi persepsi dan tingkah lakunya. Usia di bawah 20 tahun masih mudah menyerap informasi mengenai konseling tentang pemeriksaan ulang pasca pemasangan IUD yang selanjutnya akseptor akan rutin melakukan pemeriksaan ulang pasca pemasangan IUD. Menurut Kuncoroningrat (2017) yang dikutip oleh Nursalam (2011) mengemukakan bahwa makin tinggi tingkat pendidikan seseorang maka akan makin mudah menerima informasi sehingga makin banyak pula pengetahuan yang dimiliki. Sebaliknya pendidikan yang kurang akan menghambat perkembangan sikap seseorang terhadap nilainilai yang baru diperkenalkan (Rochma,2016). Hal ini dapat dijelaskan bahwa usia terbanyak akseptor terdapat dalam rentangan usia 20-35 tahun $(67,5 \%)$.

Sedangkan tingkat pendidikan akseptor yang terbanyak adalah SD (45\%). Akseptor dengan pendidikan terakhir SD tentu akan lebih sulit dalam proses berpikir dibanding dengan akseptor yang pendidikan terakhir SMP dan SMA. Tingkat pendidikan dan usia akseptor IUD sebelum mendapatkan konseling tentang pemeriksaan ulang pasca pemasangan IUD sangat berpengaruh dalam keberhasilan konseling tentang pemeriksaan ulang pasca pemasangan IUD. Pemeriksaan ulang harus tetap dilakukan sesuai dengan jadwal yang sudah ditentukan yaitu 2 minggu setelah insersi, 1 bulan berikutnya, 3 bulan berikutnya, 6 bulan-1 tahun berikutnya. Pemeriksaan ulang bertujuan untuk memeriksa ekspulsi sebagian, perforasi rahim, infeksi panggul, membantu mengatasi efek samping dan keluhan lain (Hartanto, 2014). Upaya yang sudah dilakukan yaitu dengan lebih sering memberikan konseling tentang pemeriksaan ulang pasca pemasangan IUD kepada akseptor IUD pada saat kegiatan posyandu, dan lebih mengaktifkan kader posyandu untuk memberikan motivasi kepada akseptor IUD untuk melakukan pemeriksaan ulang sesuai jadwal yang sudah ditentukan.

\section{Sikap Akseptor Sesudah Konseling Tentang Pemeriksaan Ulang Pasca Pemasangan IUD}

Berdasarkan observasi kedua sesudah konseling tentang pemeriksaan ulang pasca pemasangan IUD di Desa Banjarejo Kecamatan Taman Kota Madiun dengan jumlah sampel 40 orang, didapatkan bahwa $62,5 \%$ akseptor IUD memiliki sikap positif tentang pemeriksaan ulang pasca pemasangan IUD dan 37,5\% akseptor IUD memiliki sikap negatif tentang pemeriksaan ulang pasca pemasangan IUD. Hasil penelitian menunjukkan bahwa sesudah dilakukan konseling, akseptor memberi dukungan penuh terhadap pemeriksaan ulangpasca pemasangan IUD namun masih ada sebagian akseptor yang kurang percaya bahwa pemeriksaan ulang pasca pemasangan IUD merupakan yang terbaik untuk mengetahui ada atau tidaknya efek samping pemakaian IUD.

Menurut Notoatmodjo, 2015, sikap adalah respon tertutup seseorang terhadap stimulus atau objek tertentu yang sudah melibatkan faktor pendapat dan emosi yang bersangkutan baik senang-tidak senang, setuju-tidak setuju, baik-tidak baik, dan sebagainya. Menurut Hartanto,2014, tujuan konseling KB adalah untuk membantu peserta KB dalam menyesuaikan diri terhadap kondisi barunya, terutama bila ia mengalami berbagai permasalahan (nyata atau tidak nyata/semu). Semakin sering akseptor melakukan pemeriksaan ulang maka akseptor akan semakin mengerti tentang keuntungan dan kerugian serta efek samping dari penggunaan IUD. Upaya yang sudah dilakukan yaitu dengan memberikankonseling secara berkelanjutan tentang pemeriksaan ulang 
pascapemasangan IUD kepada akseptor IUD pada saat kegiatan posyandu,dan lebih mengaktifkan kader posyandu untuk memberikan motivasi kepada akseptor IUD untuk melakukan pemeriksaan ulang sesuai jadwal yang sudah ditentukan. Konseling secara berkelanjutan bertujuan untuk meningkatkan jumlah akseptor yang melakukanpemeriksaan ulang.

3. Perubahan Sikap Akseptor Sebelum dan Sesudah Konseling Tentang Pemeriksaan Ulang Pasca Pemasangan IUD

Berdasarkan hasil penelitian didapatkan- perhitungan perubahan antara sikap akseptor sebelum dan sesudah konseling tentang pemeriksaan ulang pasca pemasangan IUD yang menunjukkan bahwa terjadi perubahan sikap akseptor antara lain perubahan sikap positif sebelum konseling sebanyak $45 \%$ menjadi $62,5 \%$. Perubahan sikap negatif sebelum konseling $65 \%$ menjadi $37,5 \%$.

Berdasarkan perhitungan data manual dengan uji dan perhitungan dengan komputer, dapat diambil Wilcoxon kesimpulan Match bahwa Pairs Test ada perubahan ke arah yang lebih baik tentang sikap akseptor IUD sebelum dan sesudah konseling tentang pemeriksaan ulang pasca pemasangan IUD. Berdasarkan uji statistik dengan menolak Ho dan menerima Ha, maka peneliti berpendapat bahwa konseling yang dilakukantermasuk dalam kategori berhasil. Menurut Azwar, 2014, mengatakan bahwa sikap seseorang terhadap suatu objek adalah perasaan yang mendukung atau memihak (favorable) dan perasaan yang tidak mendukung (unfavorable). Hasil penelitian ini juga diperkuat oleh penelitian yang dilakukan oleh Kistijah (2018) yaitu adanya hubungan yang positif antara sikap dan pengambilan keputusan/tindakan. Menurut pendapat Breckler dan Wiggins yang dikutip oleh Azwar (2014), bahwa sikap yang diperoleh dari pengalaman akan menimbulkan pengaruh langsung terhadap perilaku berikutnya. Stimulus dalam penelitian ini adalah konseling, yang memiliki makna bahwa dengan stimulus berupa konseling dapat merubah sikap akseptor tentang pemeriksaan ulang pasca pemasangan IUD sehingga ada perubahan sikap akseptor sesudah dilakukan konseling tentang pemeriksaan ulang pasca pemasangan IUD. Dengan demikian dapat dipertimbangkan bahwa dengan dilakukannya konseling yang teratur oleh tenaga kesehatan (dalam hal ini mengenai pemeriksaan ulang pasca pemasangan IUD) dapat merubah sikap akseptor ke arah yang lebih baik. Keberhasilan konseling ini harus didukung oleh semua faktor yaitu usia, tingkat pendidikan, dukungan dari keluarga (suami), jarak tempat pelayanan, sikap petugas dalam memberikan konseling, serta faktor lain yang secara tidak langsung juga berpengaruh yaitu sosial ekonomi dan budaya malu yang harus dihilangkan.

\section{KESIMPULAN}

Ada perubahan ke arah yang lebih baik tentang sikap akseptor IUD sebelum dan sesudah konseling tentang pemeriksaan ulang pasca pemasangan IUD.

\section{REFERENSI}

Arikunto, S. (2012). Prosedur Penelitian Suatu Pendekatan Praktek. Jakarta: Rineka Cipta

Azwar, S. (2014). Sikap Manusia Teori dan Pengukurannya. Jogyakarta: Pustaka Pelajar

BKKBN. (2018). KIE dalam layanan KB. http://webcache.googleusercontent.com (diakses 26 September 2019)

Hartanto, Hanafi. (2014). Keluarga Berencana dan Kontrasepsi. Jakarta: Pustaka Sinar Harapan

Kistijah. (2018). Jurnal Penelitian Politeknik Kesehatan Surakarta Volume 1 Nomor 1. Surakarta

Latipun. (2016). Psikologi Konseling. Malang: UMM Malang 
Notoatmodjo, S. (2014). Promosi Kesehatan, Teori dan Aplikasi. Jakarta: Rineka Cipta

Notoatmodjo, S. (2015). Pendidikan dan Perilaku Kesehatan. Jakarta: RinekaCipta

Nursalam. (2011). Konsep \& Penerapan MetodologiPenelitianIlmuKeperawatan: Pedoman Skripsi, Tesis, dan Instrumen Penelitian.Jakarta: Salemba Medika

Rochma, S. (2016). Jurnal Kesehatan Edisi IV. Surabaya

Saifudin, Abdul Bari dkk. (2013). Buku Panduan Praktis Pelayanan Kontrasepsi. Jakarta : YBPSP

Sugiyono. (2009). Statistika Untuk Penelitian. Bandung : Alfabeta

Sugiyono. (2010). Statistik Non Parametrik. Bandung : Alfabeta

Sumekto. (2018). Menggapai Sasaran Kependudukan dan KB Rencana Pembangunan Jangka Menengah 20142019. (Internet) september 2019. Bersumber dari: http://muchrojimahmad.blogspot.com/20 18/10/plusminus-alat-kontrasepsihormonal.html (diakses 21 September 2019)

Sumekto. (2016). Alat Bantu Pengambilan Keputusan Ber-KB (ABPK), Edisi Keenam.

Sumekto. (2010). Akseptor IUD Di Jember. http://www.kompas.com (diakses 12Januari 2011)

Sumekto. (2001). Diantara Banyak Pilihan. http://www.gatra.com/2018-0719/artikel.php?id=8244 (diakses 12 September 2019) 